Prof. Radoje Brković*, LL.D.,

ПРЕГЛЕДНИ НАУЧНИ РАД

Full Professor,

$10.5937 /$ zrpfn0-23397

Faculty of Law, University of Kragujevac

Dejan Vučinić ${ }^{*}$, LL.M.,

PhD student, Teaching Associate,

Faculty of Law, University of Kragujevac

UDK: 331.5:305-055.1/.2

Рад примљен: 30.09.2019.

Рад прихваћен: 11.06.2020.

\title{
EQUAL OPPORTUNITIES AND TREATMENT IN EMPLOYMENT AND OCCUPATION
}

\begin{abstract}
This paper analyzes international standards relating to discrimination in terms of employment and occupation, which are primarily contained in the legal instruments of the International Labor Organization. The above standards are contained in the Convention no. 111. and Recommendation no. 111 of 1958, as well as Convention no. 100 and Recommendation no. 90 relating to the equal rewarding of male and female labor force. In particular, the author analyzes the problems and obstacles arising in the application of international standards related to the issue of discrimination in employment and occupation, and standards pertaining to the equal rewarding of male and female labor force for equal work, i.e. for work of equal value.
\end{abstract}

Keywords: discrimination in employment and occupation, equal rewarding of male and female labor force, Convention no. 111 and no. 100, Recommendation no. 111 and no. 90, application.

\footnotetext{
*rbrkovic@jura.kg.ac.rs

*dvucinic@jura.kg.ac.rs

** Рад је био изложен у виду усменог саопштења на Међународној научној конференцији „Право и мултидисциплинарност“ одржаној на Правном факултету Универзитета у Нишу 12. и 13. априла 2019.
} 


\section{Introduction}

The principle of equality is indispensable in defining the modern rule of law and providing for the exercise, enjoyment and protection of human rights and freedoms. This principle permeates all kinds of human relations and all areas of social, political, legal, economic life.

The meaning of the term 'equality' is not fully defined; it varies depending on the context in which it is applied as well as on the historical period which it is related to. Generally speaking, the broadest conception of equality encompasses the equality of subjects in different spheres (political, economic, social sphere, etc.). Equality of individuals in the context of employment and occupation is only one aspect of that equality.

In general, the idea of equality in human rights and dignity has had a long period of development. Chronologically, Aristotle's teaching about the innate weakness of women and men in the role of a tutor is the best illustration of the ancient period conceptions on equality. The Middle Ages, the age of feudalism and patriarchy, also did not bring about any significant changes regarding the position of women. Even in its early stages, capitalism did not significantly contribute to the equality of men and women, but embraced and maintained gender inequality.

The essential struggle for equality of men and women may be traced back to the French Revolution of 1789. First, the pursuit for equality in citizens' political rights was the basis that would later lead to equality of men and women in the right to vote, the right to private property, and the right to an equal exercise of parental rights. Second, the adoption of international and national documents since the late $19^{\text {th }}$ century has also been a significant step towards improving the legal position of women and providing for formal (legal) equality of men and women. Finally, international declarations proclaiming equality in human rights and dignity prohibit discrimination on various grounds, and numerous conventions and recommendations adopted by relevant international organizations establish the specific obligations of States to work towards providing substantive equality in the exercise of human rights and prohibition of discrimination.

In the context of the given topic, the relationship between equality and discrimination is an indispensable issue. Legal science has not provided a unanimous or generally accepted opinion on this issue, but there are many individual interpretations that are more or less acceptable. At first glance, these two concepts seem very similar, and it may be proper to look at them together because it is impossible to speak of equality without speaking about discrimination, and vice versa. This issue will be analyzed further on in this paper, by exploring the international standards governing equality of opportunity and treatment in 
respect of employment and occupation, as well as the aspect of implementation and difficulties arising in the application of the mentioned standards.

\section{Equality of opportunities and treatment of men and women in employment and occupation}

Equality of opportunity and treatment has two aspects. Namely, for both men and women to reach the stage of doing certain work, they need to have the same "starting positions" ${ }^{1}$ (Radovanović, 2012: 16). The standard "equal opportunities" practically means that everyone is given equal opportunities and access to resources, i.e. to perform work as a type of economic activity of an individual, as well as an equal opportunity for an individual to develop and improve their talents and abilities. In the context of gender equality, the principle of equal opportunities implies the same starting position as men. It also means equal rights, duties and responsibilities of men and women. According to some authors, this principle "opens the way to economic prosperity and political participation of the discriminated population" and "contributes to the security of society, tolerance and justice, and thus exposes society to social conflict" (Hemon-Djerić, 2014: 14).

The second aspect concerns the equal treatment of men and women at work. This standard is best achieved by establishing equal and objective criteria with respect to both sexes. This principle is also respected in situations where someone is disadvantaged, if it has been done on the basis of the objective criteria. Benefits that may also put someone in a better position than other workers, based on the objective criteria, do not mean different treatment than others. The mere existence of objective (public) criteria that applies to all employees (of both sexes) ensures equal treatment for both men and women. Any subjective assessment of personal merit by the employer is not permitted (Radovanović, 2012: 17).

\section{Gender equality and discrimination at work}

The issue of discrimination is an indispensable issue when it comes to equal opportunities and equal treatment. Discrimination is usually represented as making any difference on the basis of one's personal characteristics and disadvantaging another. Race, religion, ethnicity, gender, (etc.) are the reasons for the unequal treatment of employees or employed persons (Mihajlović, 2015: 155-176). The original concept of discrimination implied "evil intent" or "per-

1 It entails all factors that lead to equal opportunities, such as equal access to education, equal access to jobs, equal pay for equal work (etc.), which specifically pertains to women. 
sonal antipathy", and the deprivation of rights under these circumstances was harmful. However, the modern concept of discrimination is based on the principle of "equal protection" (Brković, Urdarević, 2002: 56-80).

We mentioned at the outset that equality and discrimination are terms that are closely related but they do not signify the same because the path to equality goes beyond the prohibition of discrimination. Equality does not immediately mean non-discrimination because sometimes persons may be collectively disadvantaged and also at the same time collectively discriminated against (OSCE: 2004: 12). For this reason, when assessing whether there was discrimination in a particular case, one should proceed with extreme caution; for, "if there is no unequal treatment or difference in treatment in a comparable situation, there is no discrimination" (Popović, 2014: 27). It may be said that equality and nondiscrimination are complementary, and may be pictorially represented as "the two sides of the same coin".

According to the European Commission against Racism and Intolerance (ECRI), discrimination is defined as any different treatment of a person or group of persons on a prohibited basis, without any objective and reasonable justification (ECRI, 2018: 5). ${ }^{2}$ The prohibited grounds contained in the international documents are generally enumerated, and the differences relate to the scope of these documents and territorial validity. It is also important who adopts them; thus, there are international documents or standards at the global level(UN documents such as declarations, Law of the Sea instruments), communal legal acts at the European Union level (Conventions, Recommendations), and national anti-discrimination documents (legislative acts) or regulations (bylaws, strategies, etc.).

As discrimination may be expressed in different ways, depending on the context, we can distinguish several aspects of discrimination:positive and negative discrimination, direct and indirect (latent) discrimination, institutional and structural discrimination, etc. It is interesting that discrimination can be performed on several different grounds at the same time, which is especially prominent in terms of women; thus, a woman may be discriminated against at work on the grounds of gender, economic status (poverty), single motherhood, etc. (Beker, 2010:60). In the context of equality, the aspect of decent work is also essential (Kovačević-Perić, 2018: 267-283). The consequences of discrimination

2 ECRI-JA General Policy Recommendation no. 7 (point 1, subparagraph b), On national legislation to combat racism and racial discrimination, adopted 2002, amended. 2017, ECRI, 2018; accessed on 10.07.2019.

https://www.coe.int/en/web/european-commission-against-racism-and-intolerance/ recommendation-no.7 
not only affect the worker, but it can happen that the employer himself suffers damage due to worker disloyalty and bad reputation (Bilić, Buklijaš, 2006: 78). ${ }^{3}$

In the next part of this article, we will look at the most important international instruments regulating the issue of equal opportunities and equal treatment of men and women and the way in which this area is regulated.

\section{General international standards and standards of the International Labor Organization regarding equality}

There are numerous international documents promoting the principle of equality. In chronological terms, since the adoption of the United Nations Charter of 1945, one of the goals of this international institution has been to reaffirm faith in the fundamental rights of man, in the dignity and value of the human personality, in the equality of men and women and of nations large and small, to ensure economic and social progress, improvement of living conditions, and to improve and encourages respect for rights and fundamental freedoms for all regardless of race, gender, language or religion. ${ }^{4}$

The Universal Declaration of Human Rights (UDHR) of 1948 emphasizes that the rights and freedoms proclaimed therein belong to every individual, regardless of their own differences, such as race, color, gender, language, religion, political or any other opinion, national or social origin, property, birth or other status (Article 2 UDHR) 5 .

A number of other international instruments are also relevant, such as: the Convention on the Elimination of All Forms of Racial Discrimination (1965), ${ }^{6}$ the Convention on the Elimination of All Forms of Discrimination against Women (1979), ${ }^{7}$ and the Convention against Discrimination in Education (1960). ${ }^{8}$

3 More on this: Bilic A., Buklijaš B, International Labor Law, Split, 2006, p. 78.

4 Povelja Ujedinjenih nacija, Službeni list FNRJ,,Medjunarodni ugovori”, br.4/1945.(Preamble to the United Nations Charter (1945),https://www.un.org/en/sections/un-charter/preamble/ index.html

5 Universal Declaration of Human Rights (1948), https://www.un.org/en/universaldeclaration-human-rights/

6 Convention on the Elimination of All Forms of Discrimination, "Službeni glasnik FNRJ br. 6 / 1967.https://www.ohchr.org/Documents/ProfessionalInterest/cerd.pdf

7 Convention on the Elimination of All Forms of Discrimination against Women, ("Službeni glasnik FNRJ"), 11/1981.https://www.ohchr.org/Documents/ProfessionalInterest/cedaw.pdf 8 Convention Against Discrimination in Education, ("Službeniglasnik FNRJ, 4/1964) http://portal.unesco.org/en/ev.php-URL_ID =12949\&URL_DO =DO_TOPIC\&URL_ SECTION=201.html 
Apart from the aforesaid documents which explicitly contain equality standards, there is a number of others documents that indirectly promote the principle of equality, but they will not be analyzed in detail on this occasion.

Bearing in mind that discrimination is most immanent in the field of labor and labor relations, the United Nations has paid particular attention to the protection of labour rights through the normative activity of the International Labor Organization (ILO). In this respect, two ILO conventions and their accompanying recommendations are particularly relevant to the principle of equality in the field of labour. These are: the ILO Convention No. 100 on equal remuneration of male and female workforce for work of equal value (1951) ${ }^{9}$ and the accompanying Recommendation (No. 90) to the 1951 Equal Remuneration Convention, and the ILO Convention no. 111 on Occupational and Employment Discrimination $(1958)^{10}$ and the accompanying Recommendation to the 1958 Convention.

The importance of these Conventions is supported by the fact that they are part of the core conventions of the International Labor Organization (Brković, Vučinić, 2018: 307-322). The core conventions contain the basic and most important rights, as they were adopted in the first stages of the ILO normative activity. Their importance and values were reaffirmed by a separate ILO Declaration on Fundamental Principles and Rights at Work (1998), especially in the context of global economic conditions where large capital interests threatened to undermine even the fundamental workers' rights, established as such by numerous international instruments.

The ILO Convention no. 100 on Equal Remuneration of Male and Female Workers for Work of Equal Value (1951) ${ }^{11}$ was the first step of the International Labor Organization towards achieving equality of male and female workforce in the field of remuneration. Except in this area, the basic principle of equality extends to all other labor law institutes (Kulić, 2006: 73).

The ILO Convention No. 100 imposes an obligation on Member States to adopt the necessary regulations at national level and take all measures to enforce its provisions, i.e. to ensure effective equality in the remuneration of men and

9 Convention No.100 on Equality of Equal Opportunities for Men and Women for the Work of Equal Value, ("Službeni vesnik presidijuma Narodne skupštine FNRJ", No. 12 of 15 May 1952.) https://www.ilo.org/dyn/normlex/en/f?p=NORMLEXPUB:12100:0::NO: :P12100_ILO_CODE:C100

10 Convention No. 111 on the Prohibition of Discrimination in Employment and Occupation, (Službeni glasnik FNRJ, No.3 / 61) https://www.ilo.org/dyn/normlex/en/f?p=NORMLEXPU B:12100:0::NO::P12100_ILO_CODE:C111

11 C100-Equal Remuneration Convention (No.100), 1951)' https://www.ilo.org/dyn/normlex/ en/f?p=NORMLEXPUB:12100:0::NO::P12100_ILO_CODE:C100 
women for work of equal value (Obradović, 2011: 40). This Convention is considered contemporary (Petrović, 2009: 231), and according to the number of ratifications it is one of the most widely accepted conventions. ${ }^{12}$

The very first articles of this Convention define the key terms to which it applies; thus, the term "remuneration" means ordinary, basic or minimum wage or salary, and all other benefits payable directly or indirectly, either in cash or in kind, by the employer to the employee on the basis of the worker's employment (Article 1 (a)). Such a broad designation of remuneration was specifically targeted to cover a wide range of remuneration elements, either direct or indirect, and to create little space for abuse. In addition, the term "equal remuneration for male and female workforce for work of equal value" refers to remuneration rates established without discrimination on the basis of sex. (Article 1 (b)).

The Convention leaves some space for Member States to implement the principle of equal remuneration for men and women for equal work, including the possibility to implement the envisaged standards either by enacting specific legislation pertaining to the area concerned or through "a statutory or a recognized wagesetting mechanism", either through collective agreements concluded between employers and workers or through a combination of the above.

The provisions of the 1951 Equal Remuneration Convention No.100 were supplemented by the accompanying Recommendation No. $90(1951)^{13}$, which includes the proposed measures to encourage and facilitate the application of the principle of equal remuneration for men and women for the work of equal value (Radovanović, 2012: 185).

After some time, the International Labor Organization concluded that the 1951 Convention No. 100 was insufficient to mitigate inequalities between men and women in the field of labor, and that it was necessary to regulate other aspects besides remuneration. Thus, in 1958, the ILO adopted the Convention No. 111 on prohibition of discrimination in employment and occupation ${ }^{14}$, and its accompanying (Employment and Occupation) Recommendation (1958).

12 According to the information available at the official website of the International Labor Organization, accessed on 25.08.2019, this Convention has been ratified by 173 states. https://www.ilo.org/dyn/normlex/en/f?p=1000:11300:0::NO:11300:P11300_INSTRUMENT_ ID:312245

13 R090 - Equal Remuneration Recommendation, 1951 (No. 90) https://www.ilo.org/dyn/normlex/en/f?p=NOR MLEXPUB:12100:0::NO::P12100_ INSTRUMENT_ID:312428

14 C111 - Discrimination (Employment and Occupation) Convention, 1958 (No. 111) https://www.ilo.org/dyn/normlex/en/f?p=NORMLEXPUB:12100:0::NO::P12100_ILO_ CODE:C111 
The ILO Convention No. 111 is one of the basic instruments, which defines discrimination as: a) "any distinction, exclusion or preference based on race, color, gender, religion, political opinion, national or social origin, which has the effect of nullifying or impairing equality of opportunity or treatment in employment or occupation" (Article 1 (a), and (b)) "any other distinction, exclusion or preference which has the effect of nullifying or impairing equality of opportunity or treatment in employment or occupation as may be determined by the Member concerned after consultation with representative employers' and workers' organisations, if any , as well as with other relevant authorities." (Article 1 (b)).

The aforementioned discrimination grounds cover all types of discrimination in relation to employment and occupation, and the Convention applies to all categories of workers. In addition, the Convention establishes the objective of eliminating all discrimination in employment and occupation and invites Member States to find, in accordance with their tradition and heritage, an adequate method for implementing the envisaged principles. It does not refer only to enacting legislation or regulations but also to every other form of national policy and strategy aimed at achieving the Convention objective (Blanpain, 2004: 215). The 1958 Convention No. 111 has also been widely accepted, which is clearly evidenced by the number of ratifications. ${ }^{15}$

The application of the 1958 Convention No. 111 was supported and facilitated by the accompanying 1958 Recommendation ${ }^{16}$, which supplemented and further elaborated on the concept of discrimination in employment and occupation.

\section{National standards for equal opportunity and treatment in employment and occupation}

The constitution, as a rule, contains the general legal norms and principles which are envisaged in the positive law of a state. In the Constitution of the Republic of Serbia $(2006)^{17}$, gender equality and equality between men and women is guaranteed. Thus, in the context of constitutional principles, Article 15 (Gender Equality) specifies: "The State shall guarantee the equality of women and men and develop an equal opportunities policy."In addition, Article 21 (Prohibition

15 According to the ILO website information, accessed on 25.08.2019, this Convention has been ratified by 175 states; https://www.ilo.org/dyn/normlex/en/f?p=1000:11300:0::NO: 11300:P11300_INSTRUMENT_ID:312256

16 R111 Discrimination (Employment and Occupation ) Recomendarion (1958)https:// www.ilo.org/dyn/normlex/en/f?p=NORMLEXPUB:12100:0::NO::P12100_ILO_CODE:R111

17 Ustav Republike Srbije (Constitution of the Republic of Serbia), Službeni glasnik RS, br. 98/2006. Available in English at: http://www.ustavni.sud.rs/page/view/en-GB/235-100028/ constitution 
of Discrimination) reinforces equal protection and explicitly prohibits "any discrimination, direct or indirect, on any grounds, particularly on the basis of race, sex, nationality, social origin, birth, religion, political or other beliefs, property, culture, language, age, mental or physical disability." Due to the special importance they have, all human rights and freedoms guaranteed in the Constitution are directly applicable, as explicitly stated at the very beginning of Chapter 2 "Human and Minority Rights and Freedoms": "Human and minority rights guaranteed by the Constitution shall be implemented directly", including the said rights guaranteed by the generally accepted rules of international law, ratified international treaties and laws (Article 18). Thus, this article also prohibits any form of discrimination.

These are not the only constitutional provisions or principles regarding equality of opportunity and treatment with regard to employment and occupation. There are other provisions which reflects the principle of equality of men and women but in a more indirect way, such as the provisions on dignity and free development of individuals (Article 23), the prohibition of slavery, servitude and forced labor (Article 26), the right to equal protection of rights and to legal remedy (Article 36), which have been adopted as a standard in numerous international instruments (Obradović, 2006: 59).

Importantly, ratified international instruments (conventions) and contracts(as a source of law) are both in line with the Constitution as a source of law. However, given the subject matter of the paper, we may provisionally say that this is the most significant legal source in the field of equality and equal treatment of men and women in the field of employment and occupation. In the previous parts of this paper, we have discussed the significance of the ILO Convention No. 100 on Equal Remuneration of Men and Women for Work of Equal Value, and the ILO Convention No. 111 on the Prohibition of Discrimination in Employment and Occupation, and their accompanying recommendations.

As for the national legislation, the most important legislative act on labour-related issues is the Labor Act. ${ }^{18}$ It is a general legislative act but it also contains provisions which (relying on the Constitution) regulate the issues of discrimination and equal treatment in more detail (Jovanović, 2018: 17-39). Thus, in accordance with the principles and rights proclaimed by the Constitution, this Act also regulate issues of dismissal on the initiative employer, maternity leave, equal remuneration for work of equal value, special protection of sensitive categories of workers, compensation in case of discrimination, unequal earnings for the work of equal value, etc.

18 Zakon o radu (Labor Act), “Službeni glasnik RS” br. 24/2005, 61/2005, 54/2009, 32/2013, 75/2014, 13/2017-odluka US, 113/2017 i 95/2018 - autentično tumačenje. 
In addition to the LabourAct, Serbian legislation includes subject-specific legislative acts governing labor relations in particular occupations, such as the Civil Servants Act ${ }^{19}$, where the same equality principles and non-discrimination standards are applied in specific labour areas. The principles of gender equality and the prohibition of discrimination are also explicitly envisaged in the Employment and Unemployment Insurance Act and the Occupational Safety and Health Act.

In the past ten years, the legislature has worked more intensively on developing and enacting special legislative acts on gender equality and the prohibition of discrimination, which resulted in the adoption of the Act on the Prohibition of Discrimination (2009) ${ }^{20}$ and the Gender Equality Act (2009). ${ }^{21}$ Currently, a new gender equality law is underway, which should regulate the equal position of sexes in different areas of law in line with the contemporary standards.

All of the above points to the fact that the issue of substantive equality of men and women in terms of employment and occupation is quite complex, and that adequate implementation of the principles of equality and non-discrimination cannot be adequately ensured in spite of the existing regulations. Full implementation of international standards is a challenge for the domestic legal system, as well as the inadequate implementation of existing national legislation.

\section{Instead of conclusion}

Equality of men and women, especially with regard to employment and occupation, is a an important question which has long attracted particular attention of the International Labor Organization (ILO). The long-standing practice of endangering labour-related rights, particularly of a vulnerable group of women workers, has been altered to some extent by the adoption of the ILO Conventions Nos. 100 and 111, and their accompanying Recommendations. However, given the dynamism of the world economy, global trends and many other factors, the classical labor relationship is undergoing changes, "new" or "atypical" forms of work are emerging, and the same issues have been re-actualized since the mid$20^{\text {th }}$ century.This is evidenced by the ILO Declaration on Fundamental Principles and Rights at Work (1998), which promoted the "basic conventions" of the International Labor Organization, including the conventions regulating the issue of equal treatment and non-discrimination on the basis of gender.

19 Zakon o zabrani diskriminacije (Antidiscrimination Act), Službeni glasnik RS br. 79/2005, '81/2005 - izmena, 83/2005 - izmena, 64/2007, 67/2007 - izmena, 116/2008, 104/2009, 99/2014, 94/2017 i 95/2018.

20 Zakon o zabrani diskriminacije (Antidiscrimination Act) ,,Službeni glasnik RS br.22/09..

21 Zakon o ravnopravnosti polova (Gender Equality Act), Službeni glasnik RS, br. 104/2009. 
In addition to the global tendencies and perspectives on developments in the field of labour (Poverenik, 2013:10)22, a number of other factors also create problems in the application of international standards. Namely, through the reports on the implementation of the mentioned standards, which are submitted by the member states (governments) to the International Labor Organization, it is noticeable that there are various cultural, social as well as economic problems and difficulties that impede the full implementation of the standards On the other hand, reports suggesting full and comprehensive implementation are in some cases hardly likely, which indicates the existence of both political problems and lucrative motives for individual Member States (Rončević, 2011: 223).

At the national level, it is evident that there is inadequate substantive and procedural legislation, which gives rise to a number of related issues: the inefficient national judiciary, the costs of the proceedings, the burden of proof (in discrimination) which can often deter the victim from going to court, the inadequate institutional support system to support victims of discrimination, fear of retaliation (by the employer), etc. Inadequate compensation for damage is another reason for the ongoing non-compliance with the principle of equality and nondiscrimination in employment relations.

In the past years, Serbia has encountered all these problems. Difficulties and obstacles to full implementation of international standards are a challenge for the domestic legal system. In spite of the envisaged labour-related normative framework, which has to be acknowledged, there is a need for additional legislative work on this matter. But, as one of the most common problem is the inadequate implementation of the existing legislation, there is certainly room for further improvement.

\section{References}

Beker, K. (2010) “Fenomen višestruke diskriminacije - kako do ravnopravnosti i jednakosti (The Phenomenon of Multiple Discrimination - How to achieve Parity and Equality), U: Izabrani eseji sa javnog konkursa - zaštita ravnopravnosti i promovisanje jednakosti građana, Beograd: Program Ujedinjenih nacija za razvoj, 2010

Bilić A., Buklijaš B (2006). Međunarodno radno pravo uz poseban osvrt na Međunarodnu organizaciju rada (International Labor Law with special refe-

22 Commissioner for the Protection of Equality; Republic of Serbia (2013): Izveštaj Poverenika za zaštitu ravnopravnosti (Report of the Comissioner for Equality Protection), http:// ravnopravnost.gov.rs/wp-content/uploads/2012/11/images_files_Redovan_izvestaj_2013. pdf, accessed 25.08.2019. 
rence to the International Labour Organization), Pravni fakultet Sveučilišta u Splitu, Split, 2006.

Blanpain, R. (2004), Comparative Labor Law and Industrial Relations in Industrialized Market Economies, Kluwer Law International.

Brković, R., Vučinić, D. (2018). Primena osnovnih konvencija Međunarodne organizacije rada u zakonodvstvu Srbije (Implementation of the Basic Conventions of the International Labor Organization in Serbian Legislation), U: Zbornik radova "Univerzalno i osobeno u pravu", Pravni fakultet Univerziteta u Prištini sa privremenim sedištem u Kosovskoj Mitrovici.

Brković, R., Urdarević, B. (2002), Zabrana diskriminacije prema zakonu o radu' (Prohibition of Discrimination under the Labor Act), U: Radno i socijalno pravo, Beograd br.1-3/2002

Hemon-Đerić A. (2014). Politika jednakih mogućnosti u Evropskoj Uniji i autonomnoj pokrajini Vojvodini: rodna ravnopravnost i diskriminacija u domenu zaposlenja (Equal Opportunities Policy in the European Union and in the Autonomous Province of Vojvodina: Gender Equality and Employment Discrimination), Zavod za ravnopravnost polova, Novi Sad

Jovanović, P. (2018). Načelo jednakosti u radnom pravu (The Principle of Equality in Labor Law), U: Zbornik radova Pravnog fakulteta u Novom Sadu, Novi Sad, br.1(2018)

Kulić, Ž. (2006), Radno pravo (Labor Law), Megatrend Univerzitet Beograd, Beograd

Kovačević-Perić, S. (2018). Perspektiva dostojanstvenog rada u Republici Srbiji sa aspekta zapošljavanja (Prospects for Dignified Work in the Republic of Serbia, from Employment Perspective), U: Pravniživot, časopis za pravnu teoriju i praksu, br.11/2018, Udruženje pravnika Srbije, Beograd .

Mihajlović, V. (2015). Jednakost (jednaka zaštita prava) i zabrana različitih vidova diskriminacije (Equality, Equal Protection of Rights and Prohibition of Different Forms of Discrimination), U: Pravna riječ, časopis za pravnu teoriju i praksu, br 42/2015, Udruženje pravnika Republike Srpske, Banja Luka.

Obradović, G. (2011). Primena međunarodnog standarda rada (Application of International Labor Standards), Pravni fakultet Univerziteta u Nišu, Centar za publikacije, Niš

Obradović, G. (2006). "Načelo slobode rada" -doktorska disertacija - neobjavljena, (The Principle of Freedom of Labour, unpublished doctoral dissertation), Pravni fakultet Univerziteta u Nišu, Niš. 
Popović, M. (2014). Diskriminacija i mobing u sudskoj praksi (Discrimination and Mobbing in Judicial Practice), Glosarijum, Beograd.

Petrović, A. (2009). Međunarodni standardi rada (International Labor Standards), Pravni fakultet Univerziteta u Nišu, Centar za publikacije, Niš.

Rončević, D. (2011). "Primena akata Međunarodne organizacije rada u nacionalnim zakonodavstvima"-doktorska disertacija-neobjavljena, (Implementation of International Labor Organisation Acts in National Legislations- unpublished doctoral dissertation), Pravni fakultet u Kragujevcu, Kragujevac.

Radovanović, D. (2012), Jednakost mogućnosti i tretmana muškaraca i žena u pogledu zapošljavanja i zanimanja"-doktorska disertacija- neobjavljena), (Equality of opportunities and treatment of men and women in terms of employment and occupation -unpublished doctoral dissertation), Pravni fakultet Univerziteta u Nišu, Niš.

International Labor Organization: Ratifications of C100 - Equal Remuneration Convention, 1951; https://www.ilo.org/dyn/normlex/en/f?p=1000:11300:0::N 0:11300:P11300_INSTRUMENT_ID:312245, accessed 08/25/2019.

OSCE (2004). Jednake mogućnosti (Equal Opportunities), Organizacija za sigurnost i saradnju u Evropi, OSCE, Beograd.

Poverenik za zaštitu ravnopravnosti (2013): Zbornik mišljenja, preporuka i upozorenja Poverenika za zaštitu ravnopravnosti: diskriminacija u oblasti rada i zapošljavanja (2013), (Commissioner for Equality Protection of (2013): Collection of opinions, recommendations and warnings by the Commissioner for Equality Protection on Discrimination in Labor and Employment), Beograd, available in English at: http://ravnopravnost.gov.rs/wp-content/uploads/2013/03/ jdownloads_files_manual_for_fight_against_discrimination_at_work.pdf

Legal documents

ECRI General Policy Recommendation no. 7 (point (1) (b), On national legislation to combat racism and racial discrimination, adopted 13 Dec. 2002, amended 7 Dec. 2017, the European Commission against Racism and Intolerance (ECRI), Council of Europe, Strasbourg,2018;https://rm.coe.int/ecri-general-policyrecommendation-no-7-revised-on-national-legislatio/16808b5aae; accessed 10/07/2019.

ILO C100 - Equal Remuneration Convention (No. 100), on Equal Remuneration of male and female workers for work of equal value, 1951: https://www.ilo.org/dyn/ normlex/en/f?p=NORMLEXPUB:12100:0::NO::P12100_ILO_CODE:C100

ILO C111 - Discrimination (Employment and Occupation) Convention (No. 111), 1958 https://www.ilo.org/dyn/normlex/en/f?p=NORMLEXPUB:12100:0::NO: :P12100_ILO_CODE:C111 
R090 - Equal Remuneration Recommendation, 1951 (No. 90) https://www.ilo. org/dyn/normlex/en/f?p=NORMLEXPUB:12100:0::NO::P12100_INSTRUMENT_ ID:312428

R111 - Discrimination (Employment and Occupation) Recomendation (1958) https://www.ilo.org/dyn/normlex/en/f?p=NORMLEXPUB:12100:0::NO: :P12100_ILO_CODE:R111

Ustav Republike Srbije (Constitution of the Republic of Serbia), Službeni glasnik $R S$, br. 98/2006. available in English at: http://www.ustavni.sud.rs/page/view/ en-GB/235-100028/constitution

Zakon o radu (Labor Act), Službeni glasnik RS, br. 24/2005, 61/2005, 54/2009, 32/2013, 75/2014, 13/2017-odluka US, 113/2017 i 95/2018 - autentično tumačenje.

\section{Проф. др Радоје Брковић,}

Редовни професор,

Правни факултет, Универзитет у Крагујевиу

Дејан Вучинић,

Сарадник у настави,

Правни факултет, Универзитет у Крагујевиу

\section{ЈЕДНАКОСТ МОГУТНОСТИ И ТРЕТМАНА У ПОГЛЕДУ ЗАПОШЉАВАЊА И ЗАНИМАЊА}

\section{Резиме}

У овом раду анализирају се међународни стандарди који се односе на дискриминацију у погледу запошљавања и занимања, који су садржани превасходно у правним инструментима Међународне организације рада. Наведене стандарде у првом реду садржеКонвенција бр. 111. и Препорука бр. 111. из 1958. године, као и Конвенција бр. 100. и Препорука бр. 90. које се односе на једнако награђивање мушке и женске радне снаге. Биће посебно анализиран аспект примене, односно проблеми који се јављају у примени наведених међународних стандарда, у погледу дискриминације код запошљавања, занимања и једнаког награђивања мушке и женске радне снаге за једнак рад, односно рад једнаке вредности.

Кључне речи: дискриминација у запошљавању и занимању, једнако награђивање мушке и женске радне снаге, Конвенција бр. 111. и бр. 100., Препорука бр. 111. и бр. 90., примена. 